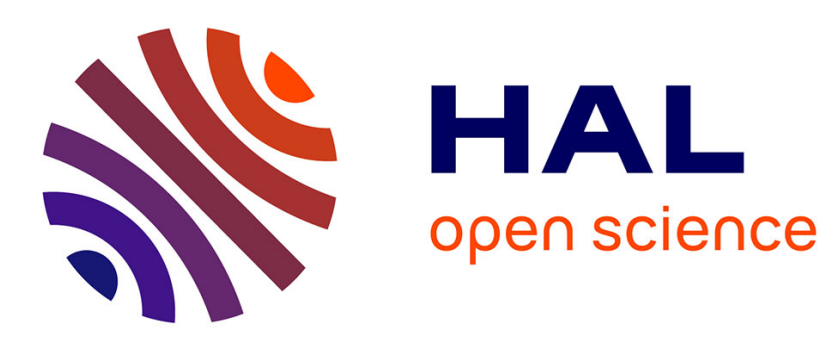

\title{
The First International Multi-Disciplinary Serial Publication Devoted to Marine Science: Les Fonds de la Mer?
}

John Dolan

\section{- To cite this version: \\ John Dolan. The First International Multi-Disciplinary Serial Publication Devoted to Marine Sci- ence: Les Fonds de la Mer?. Limnology and Oceanography Bulletin, 2020, 29 (3), pp.65-69. 10.1002/lob.10377 . hal-02996341}

\section{HAL Id: hal-02996341 https: / hal.sorbonne-universite.fr/hal-02996341}

Submitted on 9 Nov 2020

HAL is a multi-disciplinary open access archive for the deposit and dissemination of scientific research documents, whether they are published or not. The documents may come from teaching and research institutions in France or abroad, or from public or private research centers.
L'archive ouverte pluridisciplinaire HAL, est destinée au dépôt et à la diffusion de documents scientifiques de niveau recherche, publiés ou non, émanant des établissements d'enseignement et de recherche français ou étrangers, des laboratoires publics ou privés. 
The First International

Multi-Disciplinary Serial Publication Devoted to Marine Science: Les Fonds de la Mer?

\author{
Jobn R. Dolan $\odot$
}

\begin{abstract}
The first serial publication devoted to marine science appears to be a French title, published from 1867 to 1887, "Les Fonds de la Mer" (The Bottom of the Sea). It was an unusual publication, published irregularly in issues of 16 pages with plates. Very few copies exist in libraries and apparently no library holds an original complete set of the text and plates. The serial contains an early example of citizen science, reporting on the composition of sediment samples collected from around the globe by ship captains and other individuals. It provides intriguing insights into the development of marine science discipline as well as competitive aspirations of different nations in the second half of the 19th century. Many new species, largely molluscs and crustaceans, were described. Most of the species described as new were later found to be synonyms of previously described species, but today 146 of the species descriptions are recognized as valid original descriptions. Combining reports on the chemical and physical composition of sediments and benthic fauna, the first marine serial can be characterized as multidisciplinary. Les Fonds de la Mer is still being cited today.
\end{abstract}

\section{Introduction}

An academic discipline is recognizable as a distinct field of study when it has its own societies, conferences, publications, degree programs and institutes or departments; these attributes can be considered as "badges" (for lack of a better term) translating into official recognition in academia. Obviously, not all the badges are required for recognition as a distinct discipline, but one or more are needed. With regard to "Marine Science" (encompassing marine fisheries and aquaculture; biology of marine organisms; physical, chemical and biological oceanography), acquisition of the "badges" occurred over a considerable length of time. Margret Deacon described marine science in 19th and 20th century as developing in fits and starts and even experiencing some periods of near dormancy (Deacon 1971). This can be seen in the numbers of years separating the appearance of the first serial publications devoted to marine science, the establishment of permanent marine laboratories, and finally degree programs in oceanography, all relatively easily dated events.

Why bother with dating any such events? Members of an academic field share more than a similarity of study topics. They share common types of personal experiences, a particular vocabulary, and often have worked together in groups be it the lab, field, or in societies, journals, and meetings. Despite geographic dispersion and national boundaries, an academic field unites a group of individuals with a common culture of sorts and, whether aware of it or not, a common history. Part of what we share as marine scientists is the history of marine science and it bears noting from time to time that the history is respectably long.

The most easily dated events or "badges" in marine science are the relatively welldocumented establishments of marine laboratories and university degree programs. From the accounts of Kofoid (1910), in Europe the first permanent marine biology laboratories date from the 1870's with establishment of laboratories in Roscoff (1872), Naples (1874), and Kiel (1879). From the account given in Vaughan (1937), these European Laboratories were indeed the first established, and the first university Departments of Oceanography were founded at the University of Liverpool (1919), and University College Hull (1931) in the United Kingdom. Here I attempt to establish the 1867 issues of the French title Les Fonds de la Mer (The Bottom of the Sea) as the date of the appearance of the first international, multi-disciplinary, marine science serial. I first ran across the title while compiling a bibliography on early French oceanographic expeditions and was surprised at its age, predating the Challenger Expedition. The focus of the serial was on the deep-sea in general, with the subtitle being "Etude International sur les particularités nouvelles des régions sousmarines" (International study of novel features of undersea regions). 
TABLE 1 19th century marine science serials

\begin{tabular}{lll}
\hline Title & Total year range & 19th century frequency \\
\hline $\begin{array}{l}\text { Les Fonds de la Mer } \\
\begin{array}{l}\text { Wissenschaftliche } \\
\text { Meeresuntersuchungen }\end{array}\end{array}$ & $\begin{array}{l}\text { 1867-1887 } \\
\text { Journal of the Marine Biological }\end{array}$ & Annual/biannual \\
$\begin{array}{l}\text { Association of the United Kingdom } \\
\text { Wissenschaftliche }\end{array}$ & $1887-$ present & Annual/biannual \\
$\begin{array}{l}\text { Meeresuntersuchungen abt. Kiel } \\
\begin{array}{l}\text { Wissenschaftliche } \\
\text { Meeresuntersuchungen abt. Helgoland }\end{array}\end{array}$ & $1898-1936$ & semi-annual \\
Biological Bulletin & $1899-1935$ & Semi-annual \\
\hline
\end{tabular}

To my knowledge, the only catalogue of marine serials is Politz et al.'s (1990) "World List of Aquaculture and Marine Serials". Only five titles are catalogued as having been published in the 19th century and Les Fonds de la Mer is not among them. Table 1 shows publication data on the five 19th century serials from Politz et al. 1990. Unfortunately, in Politz et al. the criteria used to include or exclude titles are not given and the emphasis is stated to have been on aquaculture titles, so it is not clear why Les Fonds de la Mer was not included. Nonetheless, Les Fonds de la Mer (from here on Fonds) was first published well before these other titles according to Politz et al.'s catalogue. Other titles oddly not included in the catalogue are early journals of "conchology" and fisheries research. However, these were highly specialized, not international interdisciplinary titles.

Today, most of what we know about Fonds is due to attention given to it by malacologists as many molluscan species descriptions appeared in Fonds. The title was first described as a "rare but important work" by Iredale (1921) and later described as "exceedingly rare" by Winckworth (1941). This is because it appears that no library holds a complete printed set containing all the issues and plates (Winckworth and Fischer 1946). Rehder (1946), using different collections, reconstructed the publishing history from 1867 to 1887 in order to correctly date species descriptions published in Fonds. Oddly enough, the valid species descriptions recognized today overwhelming concern ostracods, not molluscs (see Supplementary file of Fonds species descriptions).
All of the libraries holding some Fonds catalogue it as a book rather than a serial, likely because only isolated bound volumes (periodically sets of issues of about 300 pages plus plates were published), are held in any given library. The common cataloguing of Fonds as a book may explain its omission from the Politz et al. (1990) listing of marine science serials. Here it will be shown that Fonds was indeed a serial, not a book or series of monographs (e.g., Scientific Reports of the Challenger Expedition). The establishment and contents of Fonds will then be very briefly summarized and some evidence of the value of Fonds to scientific literature will be provided.

\section{Evidence of the serial nature of Les Fonds de la Mer}

The library definition of a serial is "a publication in any medium issued in successive parts, bearing numeric or chronological designations and intended to be continued indefinitely" (AACR 2002). According to this definition, Fonds is a serial publication. It was issued in consecutively numbered "livraisons" (deliveries or issues) each consisting of 16 pages and 1 or 2 plates; subscribers paid in advance for sets of five issues (Fig. 1). Winckworth and Fischer (1946) concluded that termination of publication in 1887 with issue 81 was not planned, as the last issue did not contain summary listings or indexes, included periodically in previous issues sold as sets in "volumes".

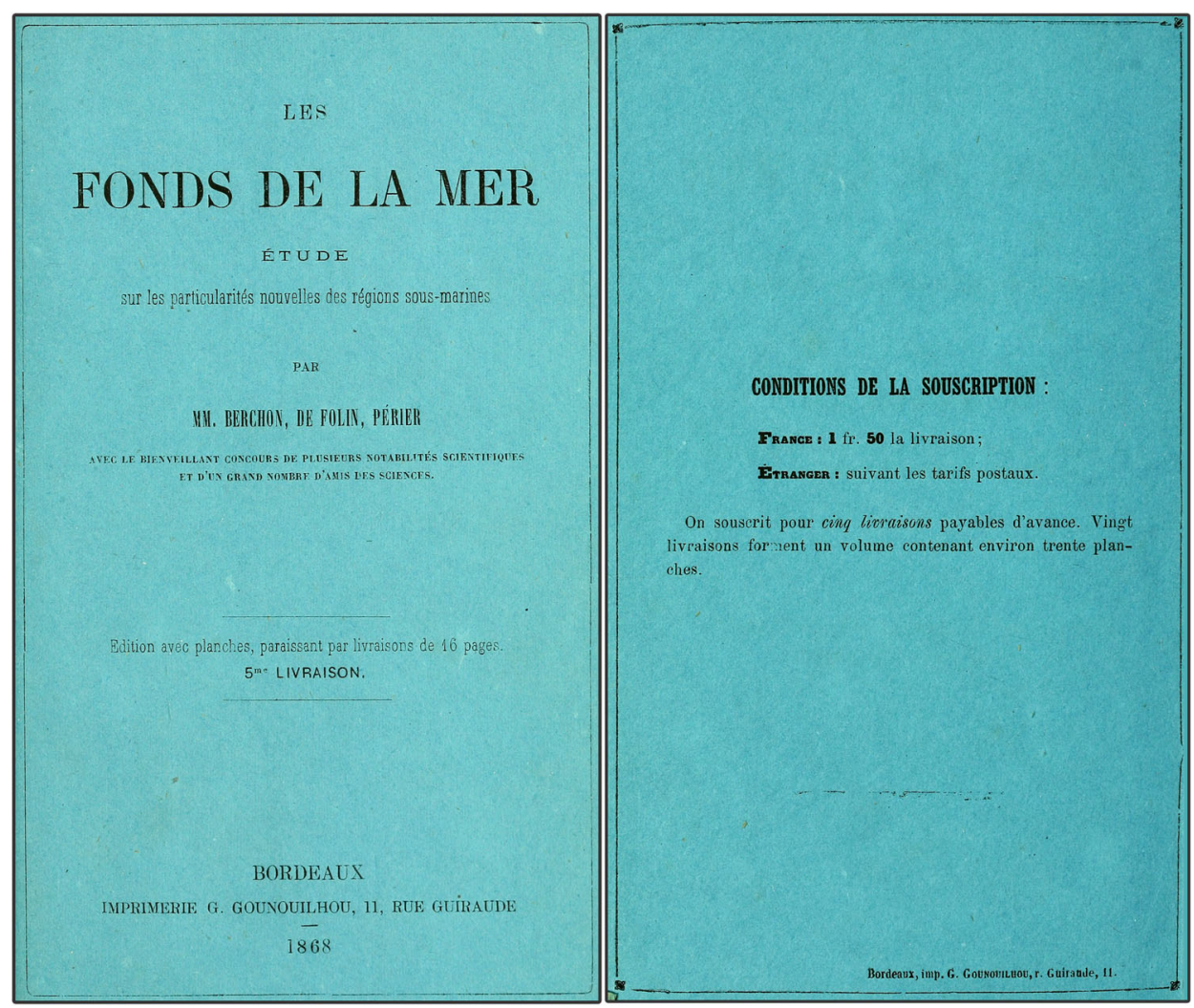

FIG 1 The front (left panel) and rear (right panel) wrappers of the 5th "livraison" (literally "delivery") or issue of Fonds, published in issues of 16 pages plus plates. Subscribers were required to pay in advance for sets of five issues. 


\section{The genesis and contents of Les Fonds de la Mer}

The introductory essay in Fonds, "Exposition", laid out the case for our basic ignorance of the depths of the sea in terms of both geology and biology compared to dry land and made the argument that if every ship were to carry out soundings and collect sediment samples knowledge of the deep-sea could be greatly increased. Such efforts were apparently well underway as the essay ends with the statement that hundreds of samples from around the world had been obtained. The essay identified the scope of the serial to be studies of the depths of the seas and was signed "Berchon, de Folin, Périer, March 1867".

The first Fonds article, (throughout the publication all articles were unauthored, and labeled chapters), was a report on samples from the Bay of Panama, giving a list of the molluscs found and describing some species. As the species descriptions are all credited to Folin, he appears to be the author of the unsigned report, similar to the eight following articles reporting on samples from diverse localities and all containing species descriptions credited to Folin. The 9th article consists of descriptions of new crustaceans by Alphonse Milne Edwards, from a sample obtained from Cape Verde: "Description des espèces nouvelles de crustacés de St. Vincent du Cap Vert". Authorship of the species descriptions and the article are commonly attributed to Milne Edwards in bibliographies (Lacroix 1926).

Fonds articles included descriptions of new species by G.S. Brady, A. Milne Edwards, L. Folin, and P. Fischer but by far most articles were short reports on the physical characteristics and chemical composition of sediments from sites around the globe. The articles in the first years appear to be based on samples gathered by a large number and variety of individuals listed at the end of issue 20 in 1872, mostly ship captains. Remarkably then, the contents of Fonds relied on an early "citizen science" collecting effort by sailors and individuals. For example, the Panama Bay samples are credited to Guillard, long-haul Capitan of Bordeaux and the Cape Verde samples are credited to Miller, English Consul at Saint-Vincent of Cape Verde. In this regard, it is worth mentioning that Léopold Folin was the Harbor
Master of the Port of Biarritz, near Bordeaux and so was well-placed to solicit and receive samples, and Folin appears to have been the primary author of articles throughout the existence of Fonds. Folin sent the samples he received to collaborators for study and then published the results of their examinations. For example, Fig. 2 is an illustration from the examination of a benthic sample from the Bay of Hong Kong by the Parisian microscopist Jules Girard. It appears in an article on ostrocods of Hong Kong (Brady 1869). The sample had been brought to Folin by the Captain Bernard of the Imperatrice Eugénie, one of the first French ocean liners, and Folin sent portions of the sample to Brady and Girard.

The strategy of relying on samples from ships traveling to and from Bordeaux and Biarritz took on a new urgency in the Fonds issue of November 1874. At that moment the Challenger Expedition was well underway and preliminary reports were being published (Wyville Thomson 1874). The Fonds article reviewing the contents of the first 7 years of publication, Folin clearly stated the patriotic desirability of continuing French citizen science sampling efforts in the face of the accomplishments of other nations:

France, can not today devote the considerable sums needed for purely scientific maritime expeditions to examine the immense depths of oceans. However, it has thousand of sailors. If each one were, each year, take the initiative to act but once, this would more than make up for our lack of means. Individual actions can provide, as has been shown here, the possibility of winning the struggle against the formidable expeditions of the United States, England and soon Germany who has already sounded the Baltic. (Folin 1874, pp. 296, my loose translation)

Folin's sentiments were echoed, nearly verbatim, in the 1874 book by Jules Girard "Les Explorations Sous-Marines" and Girard even included directions for sailors on how to collect and preserve samples. However, Léopold Folin and Alphonse Milne Edwards would soon gather their own samples by organizing and conducting the first French oceanographic expeditions of the Travailleur (Rice 1980). The expeditions were devoted

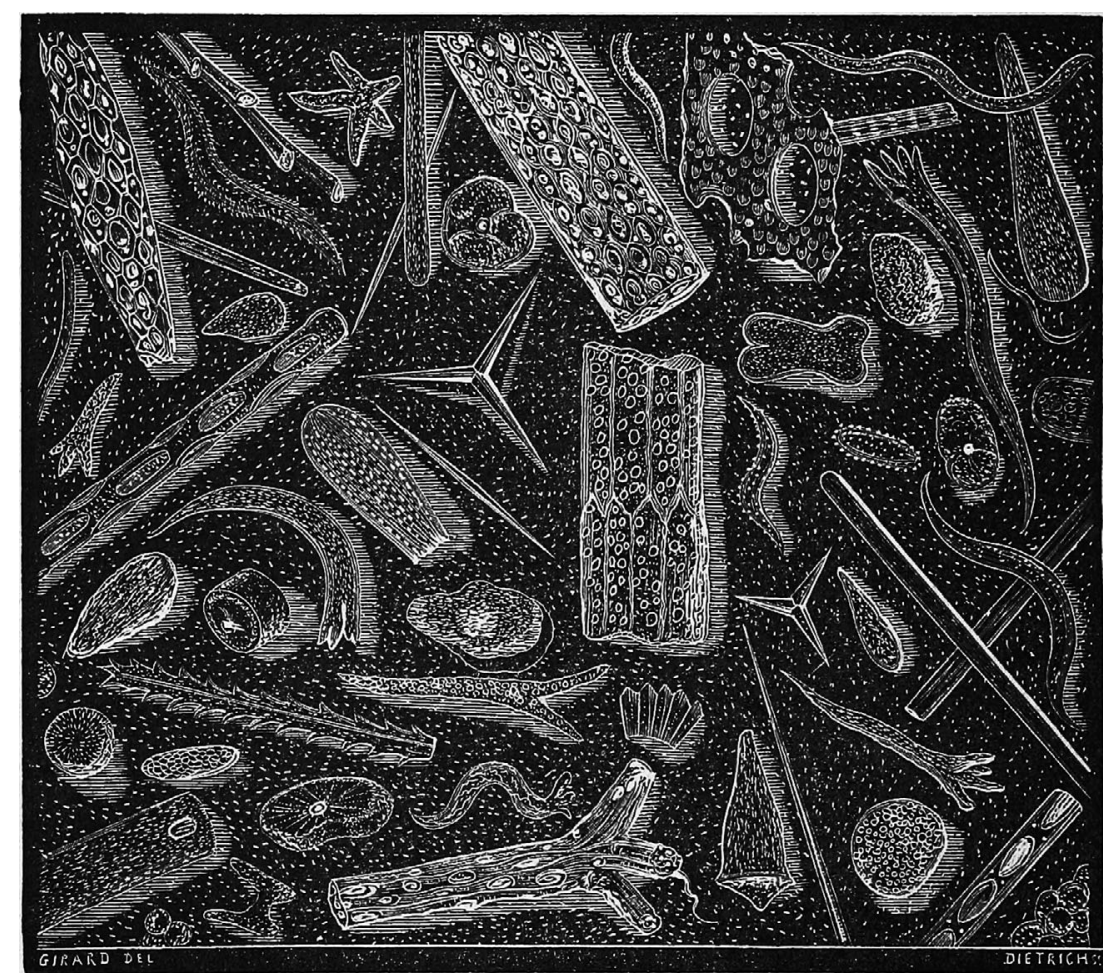

FIG 2 Microscopic view, provided by Jules Girard, of the composition of the benthos from the Bay of Hong Kong. The illustration appeared in Brady's article on ostrocods from the Hong Kong sample (Brady 1869). It shows sponge spicules, bits of coral and perhaps diatoms, ciliates, and nematodes. 


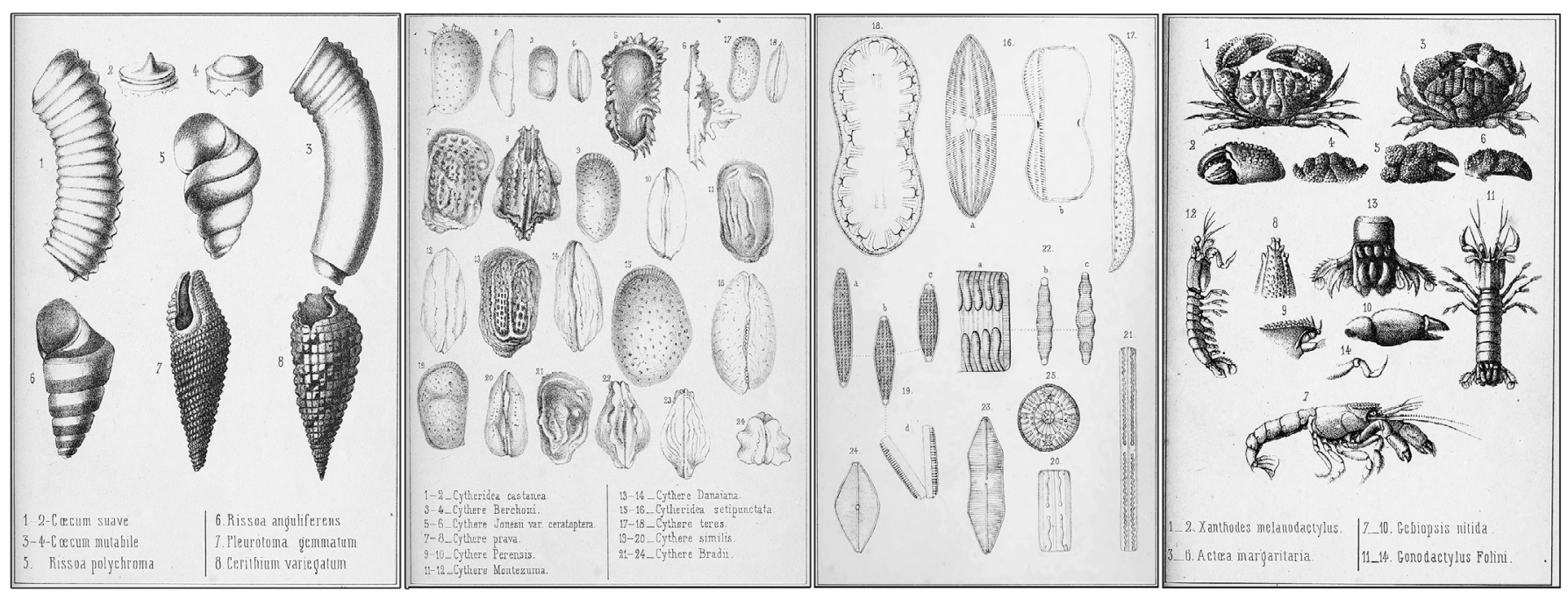

FIG 3 Some of the plates from Fonds showing the variety of species described as new. From left to right: molluscs from Folin (1869), osctracodes from Brady (1870), diatoms from Petit (1877), crabs and shrimp from Milne-Edwards (1870).

to dredging the deep. Accounts of the expeditions and many of the results would be published in the issues of Fonds.

The plates were a prominent feature of Fonds, the issue covers noted "edited with plates". Most of the plates were devoted to descriptions of new species. As remarked previously, many species descriptions appeared in Fonds, hundreds in fact. However, as is often the case, most species described as "new" are later found to have been species previously described (e.g., Appeltans et al. 2012). For example, of the diatoms shown in Fig. 3, six species were described as new. None of them are today recognized as valid first descriptions.

Admittedly, overall, a relatively small portion of the species described in Fonds are recognized today as valid first descriptions, but the absolute number, 146 species, is considerable. The complete list appears is given in the Supporting Information. The 109 ostracods described by Brady largely dominate the list of currently recognized first descriptions published in Fonds. Fig. 4 shows that most of the descriptions accepted today appeared in the early years of Fonds (1868-1870). In later years, reports on

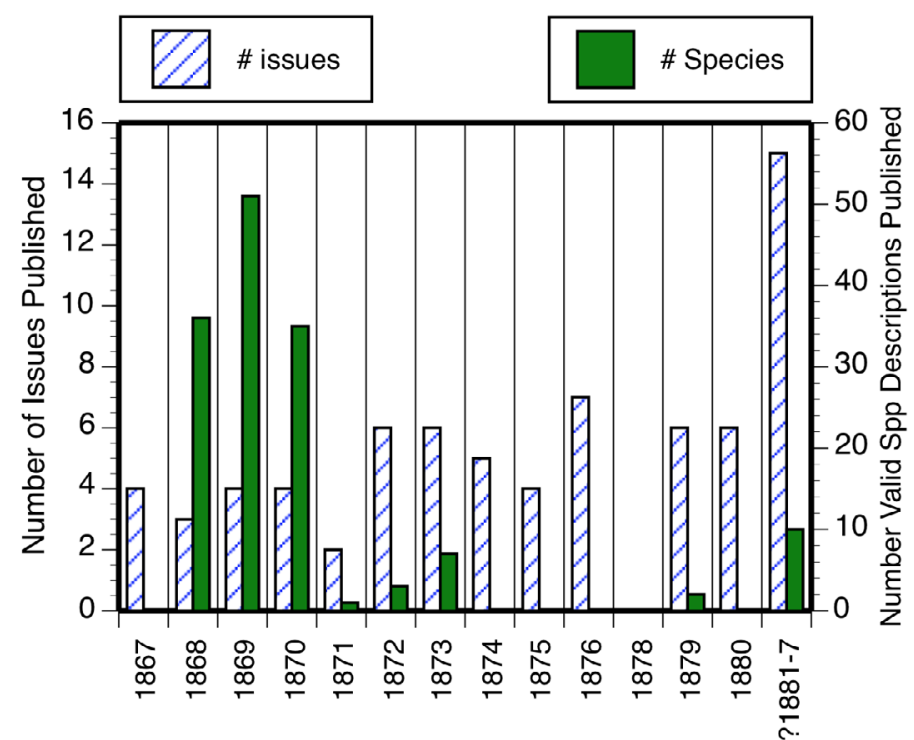

FIG 4 Publication record of Les Fonds de la Mer (based on Rehder (1946)) and the numbers of species descriptions, currently considered valid original descriptions, published in Les Fonds de la Mer by year (from WoRMS (2020)). The years ranging from 1881 to 1887 are pooled as publication dates are unclear because there are no existing copies with the original, dated covers (Fig. 1) for the last years.

sediment samples dominated the content until the last years which contained reports on deep-sea dredging using the Travailleur.

\section{"Les Fonds de La Mer" today?}

Publication of the serial ended 134 years ago. A legitimate question is, given its age and the scarcity of copies, is it used today? The common gauge of journal usage is citations and citation data show that there actually is some current usage. The lion's share of citations are to the ostracod studies of Brady and these include many citations in relatively recent articles. For example, Brady's Fonds articles were cited in six papers in 2019 and, so far, two 2020 papers. Thus it appears that despite age and scarcity of original paper copies, material published in Fonds is still used today. Actually, usage may increase in future years because since 2011 digital versions have been available through the Biodiversity Heritage Library greatly increasing its accessibility (https://www. biodiversitylibrary.org/bibliography/13261\#/ summary). However, the recent citations also show the continuing confusion over the nature of Fonds as some citations are as journal articles et al (most commonly), as chapters of an edited book.

\section{Conclusion}

The first permanent marine laboratories date back to the 1870's (Kofoid 1910) and the first Department of Oceanography dates 
back to 1919 (Vaughan 1937). Here I make the claim, that Les Fonds de la Mer was in 1867, the first serial devoted to marine science. For comparison, the first limnology journals appeared about 40 years later, in 1906, with the Archiv für Hydrobiologie, now published as Fundamental and Applied Limnology and in 1908 with the Internationale Revue der gesamten Hydrobiologie und Hydrographie now known as the International Review of Hydrobiology (Warwick Vincent, personal communication).

Claiming something as a "first" is usually unwise as one never has all the certain, complete knowledge needed to identify a "first." Somewhere, someone may know of an earlier marine science serial. If so, I can only paraphrase the famous marriage demand and ask that you speak now or forever hold your peace.

\section{Acknowledgments}

Virginia Edgcomb, Tony Rice, and Warwick Vincent kindly provided valuable comments on a previous version and invaluable encouragement.

\section{References}

AARC. 2002. American Library Association, Canadian Library Association, Library Association. Anglo-American Cataloguing Rules [AACR2]. 2nd ed., revised. ALA Editions.
Appeltans, W., and others. 2012. The magnitude of global marine species diversity. Curr. Biol. 22: 2189-2202. https://doi.org/10.1016/j. cub.2012.09.036.

Brady, G. S. 1869. Les entomostracés de HongKong. Les Fonds de la Mer 1: 155-159.

Brady, G. S. 1870. Golfe de Gascogne. Les Fonds de la Mer 1: 147-151.

Deacon, M. 1971. Scientists and the sea 1650-1900: a study of marine science. Aberdeen Univ. Press, p. 445.

Folin, L. 1869. La baie de Panama (supplément). mollusques. Les Fonds de la Mer 1: 130-139.

Folin, L. 1874. Aperçu général sur les deux premiers volumes des Fonds de la Mer, avec tableaux récapitulatifs des faits constatés par les auteurs et mentionnés dans la publication. Les Fonds de la Mer 2: 283-297.

Girard, J. 1874. Les Explorations Sous-Marines. Librarie F. Savy, p. 248.

Kofoid, C. A. 1910. The biological stations of Europe. United States Bureau of Education, bulletin no. 4, whole number 400. Government Printing Office, p. 360.

Iredale, T. 1921. Molluscan nomenclatural problems and solutions no. II. Proc. Malocol. Soc. Lond. 14: 198-208.

Lacroix, A. 1926. Notice historique sur Alphonse Milne-Edwards. Mémoires de l'Academie des Science, v. 58. Institut de France, p. I-LXXIV.

Milne-Edwards, A. 1870. Descrition des espèces nouvelles de crustacès de St. Vincent du Cap Verde. Les Fonds de la Mer 1: 34-45.

Petit, P. 1877. Abords de Campbell et de la Nouvelle-Zélande (Polynésie), Catalogue des Diatomées. Les Fonds de la Mer 3: 168-198.
Politz, M. K., D. T. Hanfman, E. M. McVey, and D. H. Goldberg. 1990. World list of aquaculture and marine serials. National Agricultural Library, US Department of Agriculture, p. 159.

Rehder, H. A. 1946. Additional notes on the dates of publication of les fonds de la mer. Proc. Malocol. Soc. Lond. 27: 74-75.

Rice, A. L. 1980. The beginnings of French oceanography: the cruise of the "Travailleur", July 1880. Oceanol. Acta 3: 266.

Vaughan, T. W. 1937. International aspects of oceanography. Oceanographic data and provisions for oceanographic research. National Academy of Sciences, p. 225.

Winckworth, R. 1941. Les fonds de la mer: dates of publication. J. Moll. Stud. 24: 149-151.

Winckworth, R., and E. Fischer. 1946. Les fonds de la mer. J. Moll. Stud. 26: 179.

WoRMS Editorial Board. 2020. World Register of Marine Species. VLIZ. Available from http://www.marinespecies.org. Accessed 2020-03-22. doi:https://doi.org/10.14284/170

Wyville Thomson, C. 1874. Preliminary notes on the nature of the sea-bottom procured by the soundings of HMS 'Challenger' during her cruise in the Southern Sea in the early part of the year 1874. Proc. Roy. Soc. Lond. Ser. I 23: 32-49. https://doi.org/10.1098/rspl. 1874.0006 .

John R. Dolan, Sorbonne Université, CNRS UMR 7093, Laboratoire d'0céanographie de Villefranche-sur-Mer, Vilefranche-sur-Mer, France; dolan@obs-vlfr.fr 